\title{
Effects of a recombinant fibrolytic enzyme on fiber digestion, ruminal fermentation, nitrogen balance, and total tract digestibility of heifers fed a high forage diet $^{1}$
}

\author{
Tao Ran, ${ }^{*, \dagger}$ Atef M. Saleem, ** Yizhao Shen, ${ }^{*, \S}$ Gabriel O. Ribeiro Jr, ${ }^{\#}$ Karen A. Beauchemin, $*$ \\ Adrian Tsang, "Wenzhu Yang, ${ }^{*, 2}$ and Tim A. McAllister* \\ *Lethbridge Research and Development Centre, Lethbridge, AB T1J 4B1, Canada; ${ }^{\dagger}$ Key Laboratory for \\ Agro-Ecological Processes in Subtropical Region, Institute of Subtropical Agriculture, The Chinese Academy

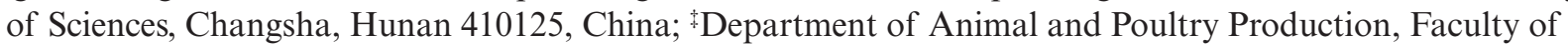 \\ Agriculture, South Valley University, Qena 83523, Egypt; ${ }^{\circledR}$ College of Animal Science and Technology, Hebei \\ Agricultural University, Baoding 071029, China; ${ }^{\#}$ Department of Production Animal Health, Faculty of \\ Veterinary Medicine, University of Calgary, Calgary, AB T2N 1N4, Canada; and $\|$ Centre for Structural and \\ Functional Genomic, Concordia University, Montreal, QC H4B 1R6, Canada
}

\begin{abstract}
A metabolism study was conducted using 8 ruminal cannulated beef heifers to investigate the effects of a recombinant fibrolytic enzyme (RFE; xylanase XYL10C) selected specifically for forage-fed ruminants on ruminal $\mathrm{pH}$, fermentation, nitrogen balance, and total tract digestibility of heifers. The experiment was a cross-over design with 2 treatments and 2 periods. The 2 treatments were a basal diet containing $60 \%$ barley silage, $30 \%$ barley straw, and 10\% supplement (DM basis) without (control) or with RFE. The enzyme was sprayed onto the barley straw at a rate of $6.6 \times 10^{4} \mathrm{IU} \cdot \mathrm{kg}^{-1} \mathrm{DM} 24 \mathrm{~h}$ before feeding. Each period comprised 2 wk of diet adaptation and $1 \mathrm{wk}$ of sampling and data collection. Feed intake and total tract digestibility of DM, OM, NDF, and ADF were unaffected by RFE. Ruminal $\mathrm{pH}$
\end{abstract}

including mean, minimum, maximum, and duration $\mathrm{pH}<5.8$, did not differ between treatments. Total VFA concentration, molar proportion of individual VFA, and acetate-to-propionate ratio were also not affected by RFE. However, ruminal $\mathrm{NH}_{3}-\mathrm{N}$ concentration $(P<0.06)$ and endoglucanase activity $(P<0.08)$ in ruminal fluid tended to be higher with RFE. Nitrogen utilization and microbial protein synthesis were not affected by treatment. These results indicate that XYL10C did not improve fiber digestion in heifers fed a high forage diet, despite the fact that it was specifically selected for this trait in laboratory assays. However, the increased ruminal $\mathrm{NH}_{3}-\mathrm{N}$ concentration suggests it potentially increased ruminal proteolytic activity.

Key words: beef heifers, fibrolytic enzyme, high forage diet, microbial protein synthesis, rumen $\mathrm{pH}$ and fermentation, total tract digestibility

(C) Her Majesty the Queen in Right of Canada, as represented by the Minister of Agriculture and Agri-Food Canada, 2019.

\footnotetext{
${ }^{1}$ The financial support for this study from Elanco Animal Health and the Agricultural Innovation Program of Agriculture and Agri-Food Canada is gratefully acknowledged. The authors thank the Lethbridge Research and Development Centre (AAFC) staff for their technical and animal care assistance. The authors thank T. Schwinghamer and L. Jin for their help with statistical analysis. The authors declare no conflicts of interest. Contribution\#: 38719020.

${ }^{2}$ Corresponding author: wenzhu.yang@canada.ca

Received April 26, 2019.

Accepted June 27, 2019.
}

J. Anim. Sci. 2019.97:3578-3587
doi: $10.1093 /$ jas/skz216

\section{INTRODUCTION}

Considerable effort has been directed towards developing and evaluating exogenous fibrolytic enzymes (EFEs) for their potential to improve the fiber digestibility and feed value of forages for ruminants (McAllister et al., 2001; Beauchemin and Holtshausen, 2010). Some EFEs have been shown 
to improve DM and NDF digestibility in vitro and in vivo (Meale et al., 2014; Tirado-Gonzalez et al., 2018). Improvements in digestibility have been linked to improvements in growth performance and milk production in ruminants, but responses have been equivocal and inconsistent (Ribeiro et al., 2018). Responses to EFE vary depending upon the nutritional needs of the animal, diet composition, enzyme formulation, dose rate, and delivery method (McAllister et al., 2001; Beauchemin et al., 2004; Beauchemin and Holtshausen, 2010). Although many EFEs are commercially available, most of them are designed for industrial processes (e.g., pulp and paper industry, cleaning products) or for monogastrics and are not optimized for the rumen (i.e., $\mathrm{pH}$, temperature). Thus, the uncertainty in the effectiveness of enzyme products, particularly the variability in responses with diet and feeding conditions, is a major impediment to the wide-spread commercial use of EFE in ruminants (Phakachoed et al., 2013).

Using rumen metagenome and metatranscriptome approaches, our group has recently selected for recombinant fibrolytic enzymes (RFEs) on the basis of their synergy with mixed ruminal microbial enzymes (Badhan et al., 2014). We hypothesized that these enzyme products would compliment rather than duplicate existing enzyme activities within the rumen (Ribeiro et al., 2016). A total of 11 different RFEs were selected using a high-throughput in vitro micro assay for their ability to increase the hydrolysis of barley straw (Ribeiro et al., 2018). A single enzyme, RFE XYL10C originating from GH10 of Aspergillus niger, was found to increase the DM disappearance of barley straw and total VFA production in batch culture (Ribeiro et al., 2018). We hypothesized that an enzyme selected on the basis of synergy with rumen enzymes would increase the total tract digestibility of fiber. Therefore, the objective of this study was to further investigate if addition of XYL10C to a high forage diet affected feed intake, ruminal $\mathrm{pH}$, ruminal fermentation, $\mathrm{N}$ metabolism, or total tract digestibility of nutrients in beef heifers.

\section{MATERIALS AND METHODS}

\section{Enzyme Product}

The RFE, XYL10C (1,4- $\beta$-xylanase, EC 3.2.1.8), was specifically selected based on its synergy with mixed ruminal enzymes through a highthroughput in vitro microassay (Badhan et al., 2014). The selection criterion was the ability of RFE to increase the hydrolysis of barley straw and release total sugar (glucose + xylose) when combined with a mixture of rumen enzymes compared with rumen enzymes alone in a high-throughput in vitro microassay. All RFEs that increased total sugar release by at least $20 \%$ when compared with the crude mixture of rumen enzymes were selected for further assessment in batch culture (Ribeiro et al., 2018). The enzyme used in the present study, produced by $A$. niger, was one of the most effective candidates of the 11 tested in that previous in vitro batch culture study. The RFE was mass produced in $100 \mathrm{~L}$ fermenters to generate sufficient quantities of enzyme for the study by Elanco Animal Health (Eli Lilly Canada Inc., Toronto, ON, Canada). The XYL10C had an average xylanase activity of 215 $\mathrm{IU} \cdot \mathrm{mg}^{-1}$ of protein determined aerobically at $39^{\circ} \mathrm{C}$ and pH 6.0 using 1\% birchwood xylan (catalog no. X-0502; Sigma Chemical Co., St. Louis, MO) as a substrate as per the manufacturer's directions.

\section{Animals, Diets, and Experimental Design}

All animal procedures and protocols used in this study were approved by the Lethbridge Research and Development Centre Animal Care Committee (ACC number 1724) in accordance with the guidelines of the Canadian Council on Animal Care (2009).

Eight Angus heifers fitted with ruminal cannulas, averaging $768 \pm 33 \mathrm{~kg}$ of $\mathrm{BW}$, were used in the study. Heifers were housed in tie stalls in the Metabolism Barn Unit (Agriculture and Agri-Food Canada, Lethbridge Research and Development Centre) and allowed daily exercise for $1 \mathrm{~h}$ in an open dry lot, except during the periods where total feces and urine were collected. Heifers were randomly divided into 2 groups of 4 and assigned to 1 of 2 treatments in a cross-over design ( 2 treatments $\times 2$ periods). In the first period, 1 group of heifers received a basal diet supplemented with RFE, while the other group was offered the basal diet without enzyme (control). A 25-d washout period was then imposed before the start of the second period, at which point the animals were switched to the other treatment. The experimental period was $36 \mathrm{~d}$, which consisted of $14 \mathrm{~d}$ for adaptation to the new treatment, followed by $7 \mathrm{~d}$ of sampling and data collection (in situ incubations were performed thereafter and reported separately).

Heifers were fed a high forage diet containing $60 \%$ barley silage, $30 \%$ barley straw, and $10 \%$ supplement containing protein, minerals, and vitamins (DM basis; Table 1). Animals were weighed on the first and last day of each period. Approximately $24 \mathrm{~h}$ prior to feeding, the enzyme was diluted with 
Table 1. Ingredients and chemical composition of the experimental diet

\begin{tabular}{|c|c|}
\hline Item & Contents \\
\hline \multicolumn{2}{|l|}{ Ingredients, $\%$ of DM } \\
\hline Barley silage ${ }^{1}$ & 60.0 \\
\hline Barley straw ${ }^{2}$ & 30.0 \\
\hline Supplement feeds & 10.0 \\
\hline Corn DDGS & 5.0 \\
\hline Canola meal & 4.0 \\
\hline Calcium carbonate & 0.147 \\
\hline Dicalcium phosphate & 0.150 \\
\hline Salt & 0.150 \\
\hline Feedlot premix ${ }^{3}$ & 0.050 \\
\hline Urea & 0.500 \\
\hline Vitamin E $\left(500,000 \mathrm{IU} \cdot \mathrm{kg}^{-1}\right)$ & 0.003 \\
\hline \multicolumn{2}{|l|}{ Chemical composition, $\%$ of DM } \\
\hline $\mathrm{DM}, \%$ & 57.2 \\
\hline $\mathrm{OM}$ & 92.8 \\
\hline $\mathrm{NDF}$ & 50.2 \\
\hline $\mathrm{ADF}$ & 30.2 \\
\hline Starch & 14.1 \\
\hline $\mathrm{CP}$ & 12.1 \\
\hline
\end{tabular}

${ }^{1}$ Composition (\%; DM basis): 35.6 DM, 92.7 OM, 47.5 NDF, 24.7 ADF, 22.8 starch, and $10.9 \mathrm{CP}$.

${ }^{2}$ Composition (\%; DM basis): 89.8 DM, 91.7 OM, 71.0 NDF, 45.2 $\mathrm{ADF}$, and 3.5 CP.

${ }^{3}$ Supplied per kilogram of dietary DM: $15 \mathrm{mg} \mathrm{Cu}, 65 \mathrm{mg} \mathrm{Zn}, 28 \mathrm{mg}$ $\mathrm{Mn}, 0.7 \mathrm{mg} \mathrm{I}, 0.2 \mathrm{mg} \mathrm{Co}, 0.3 \mathrm{mg} \mathrm{Se}, 6,000 \mathrm{IU}$ vitamin A, $600 \mathrm{IU}$ vitamin $\mathrm{D}$, and $47 \mathrm{IU}$ vitamin $\mathrm{E}$.

distilled water and sprayed onto the barley straw at $10 \%(\mathrm{vol} / \mathrm{wt})$ to achieve a rate of $6.6 \times 10^{4} \mathrm{IU}$ enzyme $\cdot \mathrm{kg}^{-1}$ straw (DM basis; $1.98 \times 10^{4} \mathrm{IU} \cdot \mathrm{kg}^{-1}$ dietary DM); the same application rate of distilled water was also added onto the straw in the control diet. The dose of RFE used was one-third of the dose used in on our previous in vitro study (Ribeiro et al., 2018), due to the large amount of RFE needed in the whole study. Samples of barley straw from both treatments were collected for chemical analysis immediately prior to feeding, to assess pretreatment effects. Diets were prepared daily using a portable feed mixer (Data Ranger, American Calan Inc., Northwood, NH).

During adaptation, heifers were fed total mixed ration (TMR) ad libitum, once daily at $1000 \mathrm{~h}$ with assurance of at least 5\% refusals, and during the collection period, heifers were restricted to $90 \%$ of their ad libitum intake (calculated based on last $7 \mathrm{~d}$ before total collection) to reduce variation in feed intake and to ensure complete consumption. Amounts of feed offered and refused were recorded daily for each heifer to calculate feed intake. Samples of diets, feed ingredients, and refusals were collected daily, mixed, and subsampled to obtain composited samples. The feed samples were dried in an oven at $55^{\circ} \mathrm{C}$ for $48 \mathrm{~h}$, ground through a 1-mm screen (standard model 4, Arthur Thomas Co., Philadelphia, PA), and retained for chemical analyses.

\section{Ruminal pH and Fermentation}

Ruminal $\mathrm{pH}$ was monitored continuously for $6 \mathrm{~d}$ from day 15 to 21 of each period using the Lethbridge Research Centre Ruminal pH Measurement System (LRCpH; Dascor, Escondido, CA). Ruminal pH readings were taken every $30 \mathrm{~s}$ and stored in a data logger (model M1b-pH-1KRTD, Dascor). Ruminal $\mathrm{pH}$ data were summarized for each heifer as mean $\mathrm{pH}$, minimum $\mathrm{pH}$, maximum $\mathrm{pH}$, and the duration of $\mathrm{pH}<5.8$. The minimum and maximum $\mathrm{pH}$ value for each treatment was obtained from the raw input data using PROC MEANS (version 16.0.0, SAS Institute Inc., Cary, NC). A ruminal $\mathrm{pH}$ of 5.8 was chosen as benchmark because this threshold value is often associated with a depression in fiber digestion (Sung et al., 2007).

The determination of ruminal fermentation characteristics was carried out on day 15 and 21 by collecting rumen samples at $0,3,6$, and $9 \mathrm{~h}$ after feeding. An equal mixture of ruminal liquid and solids ( $\sim 300 \mathrm{~g})$ were collected from the reticulum, dorsal, and ventral sites within the rumen and immediately squeezed through 4 layers of cheesecloth. Filtrates ( $5 \mathrm{~mL}$, each) were mixed with $1 \mathrm{~mL}$ of $25 \%$ metaphosphoric acid for analysis of volatile fatty acid (VFA), and $1 \mathrm{~mL}$ of $1 \%$ (wt/vol) sulfuric acid for $\mathrm{NH}_{3}-\mathrm{N}$ analysis or preserved in methyl greenformalin-saline for enumeration of total protozoa. Filtrates collected at 0 and $6 \mathrm{~h}$ after feeding were used to determine enzyme activity (xylanase, endoglucanase, and exoglucanase). All samples were stored at $-20^{\circ} \mathrm{C}$ until analyzed.

\section{Digestibility, N Balance, and Microbial Protein Synthesis}

Urine was collected by inserting urine catheters (26 French, 75-cc ballon; C. R. Bard, Inc., Covington, GA) into the bladder of each heifer and feces were collected using pans placed behind the animals from day 16 to 20 . The individual total quantity of feces and urine excreted was recorded daily, and representative samples (5\% wet weight) were collected and composited by period for each heifer. The composited fecal samples were dried at $55{ }^{\circ} \mathrm{C}$ for $48 \mathrm{~h}$, ground through a $1-\mathrm{mm}$ screen (standard model 4, Arthur Thomas Co.), and retained for chemical analysis. 
Bacterial pellets were prepared as described by Yang and Beauchemin (2006). Briefly, a mixed ruminal liquid and solid sample $(\sim 0.8 \mathrm{~L})$ from various locations within the rumen was collected from each heifer $3 \mathrm{~h}$ after feeding on day 15 and 21 . Samples were squeezed through 4 layers of cheesecloth and the retained particles ( 400 g wet) were blended for $3 \mathrm{~min}$ with an equal amount of saline in a Waring blender (Waring Products Division, New Hartford, CT). The blended homogenate was mixed, centrifuged at $800 \times g$ for $10 \mathrm{~min}$ at $4{ }^{\circ} \mathrm{C}$ to remove protozoa and feed particles, and the supernatant was collected. The supernatant was centrifuged at $27,000 \times g$ for $30 \mathrm{~min}$ at $4{ }^{\circ} \mathrm{C}$ to obtain a mixed bacterial pellet. Bacterial pellets were composited by period for each heifer, freeze-dried, and ball ground using a ball mill (Mixer Mill MM2000; Retsch, Haan, Germany), and stored for analysis of total $\mathrm{N}$ in mixed rumen bacteria.

Urine was collected in 20-L plastic buckets containing a sufficient quantity of acid $(0.5 \mathrm{~L}$ of $4 \mathrm{~N}$ $\mathrm{H}_{2} \mathrm{SO}_{4}$ ) to reduce urine $\mathrm{pH}$ to $<2.5$. The volume of urine excreted was recorded daily from day 16 to 20 , and a $5 \mathrm{~mL}$ subsample was collected, diluted with $20 \mathrm{~mL}$ of distilled water, and stored at $-20^{\circ} \mathrm{C}$. Samples were analyzed for urea $\mathrm{N}, \mathrm{NH}_{3}-\mathrm{N}$, allantoin, uric acid, and total N. Total purine derivatives (PDs) excreted $\left(\mathrm{mmol} \cdot \mathrm{d}^{-1}\right)$ were estimated as the sum of uric acid and allantoin. Excretion of the endogenous PD was assumed to be constant at $0.385 \mathrm{mmol} \cdot \mathrm{kg}^{-1}$ of $\mathrm{BW}^{0.75}$ for each heifer (Chen and Gomes, 1992). Purine absorption of microbial origin was calculated as: (total PD excreted - endogenous PD)/0.85 (Chen and Gomes, 1992). Synthesis of microbial $\mathrm{N}$ within the rumen was calculated as: (purine absorption $\times 70) /($ purine $\mathrm{N}$ :total $\mathrm{N}$ in mixed rumen bacteria $\times 0.83 \times 1,000)($ Chen and Gomes, 1992).

\section{Chemical Analyses}

Chemical analyses were performed on each sample in duplicate, and analysis was repeated when the $\mathrm{CV}$ for the replicate analysis was more than $5 \%$. Dry matter content of the ingredients (silage, straw, supplement) and TMR was determined by oven drying at $55^{\circ} \mathrm{C}$ for $48 \mathrm{~h}$. Analytical $\mathrm{DM}$ was determined by drying at $135^{\circ} \mathrm{C}$ for $2 \mathrm{~h}$ [Association of Official Analytical Chemists (AOAC) International, 2005; method 930.15]. Ash content of feeds and feces was determined by combustion at $550{ }^{\circ} \mathrm{C}$ for $5 \mathrm{~h}$, and organic matter (OM) content of feeds and feces was calculated as the difference between 100 and ash content (AOAC
International, 2005; method 942.05). Neutral detergent fiber (NDF) of feeds and feces was determined as described by Van Soest et al. (1991) using heatstable $\alpha$-amylase (Termamyl 120 L, Novo Nordisk Biochem, Franklinton, NC) without sodium sulfite. Acid detergent fiber (ADF) of feeds and feces was determined according to AOAC International (2005; method 973.18). Starch in feed and feces was analyzed by enzymatic hydrolysis of $\alpha$-linked glucose polymers as described by Rode et al. (1999). The flash combustion and thermal conductivity detection technique (model 1500, Carlo Erba Instruments, Milan, Italy) was used to analyze the concentration of total $\mathrm{N}$ in feed offered, refusals, fecal samples, and bacterial pellets. Crude protein content was calculated as $\mathrm{N} \times 6.25$. Water-soluble carbohydrate (WSC) in control or enzyme-treated barley straw was measured using modified NelsonSomogyi method (Hatanaka and Kobara, 1980).

Ruminal VFAs were separated and quantified using a gas chromatograph (model 5890, Hewlett-Packard Lab, Palo Alto, CA) equipped with a capillary column $(30 \mathrm{~m} \times 0.32 \mathrm{~mm}$ i.d., $1-\mu \mathrm{m}$ phase thickness, Zebron ZB-FAAP, Phenomenex, Torrance, CA), and flame ionization detection and using crotonic acid (trans-2-butenoic acid) as an internal standard. Concentration of $\mathrm{NH}_{3}-\mathrm{N}$ in the ruminal contents was determined as described by Rhine et al. (1998). Ruminal protozoa were counted using a Fuchs-Rosenthal counting chamber (Hausser Scientific Partnership, Horsham, PA). Allantoin in urine was determined using autoanalyzer as described by Lindberg and Jansson (1989). Uric acid was determined using a commercial kit (no. 292; Sigma Chemical Co.).

Xylanase activity of rumen contents was measured according to Bailey et al. (1992), and one enzyme activity unit (U) was defined as the amount of enzyme required to release $1 \mathrm{mmol}$ of xylose equivalents $\cdot \mathrm{min}^{-1} \cdot \mathrm{g}^{-1}$ (wet material). Endoglucanase and exoglucanase activities were determined as described by Wood and Bhat (1988), and one enzyme activity unit (U) was defined as the amount of enzyme required to release $1 \mu \mathrm{mol}$ of glucose equivalents $\cdot \mathrm{min}^{-1} \cdot \mathrm{g}^{-1}$ of wet rumen contents.

\section{Statistical Analyses}

Data for feed intake, digestibility, $\mathrm{N}$ balance, and microbial protein synthesis were analyzed using the PROC MIXED procedure of SAS (version 16.0.0, SAS Institute Inc.), with treatment considered as a fixed effect, day of sampling as a repeated measure, and period and heifer considered as random effects. 
Data for ruminal $\mathrm{pH}, \mathrm{VFA}, \mathrm{NH}_{3}-\mathrm{N}$, protozoa enumeration, and enzyme activity were analyzed using the mixed model procedure of SAS with sampling day and sampling time within day considered as repeated measurements. For repeated measures, various covariance structures were tested and AR(1) was selected based on the lowest value for Akaike's information criteria. Effects of the factors were declared significant at $P \leq 0.05$ and tendencies were discussed at $0.05<P \leq 0.10$ unless otherwise stated.

\section{RESULTS}

\section{Barley Straw Chemical Composition, Feed Intake, and Digestibility}

The chemical composition including DM, OM, NDF, ADF, CP, and WSC of barley straw treated with or without enzyme did not differ (Table 2). As expected, intakes of DM, OM, NDF, ADF, starch,

Table 2. Effects of recombinant fibrolytic enzyme supplementation on chemical composition of barley straw, intake, and digestibility in the total digestive tract of heifers fed forage diet

\begin{tabular}{|c|c|c|c|c|}
\hline \multirow[b]{2}{*}{ Item $^{1}$} & \multicolumn{2}{|c|}{ Treatments $^{2}$} & \multirow[b]{2}{*}{ SEM } & \multirow[b]{2}{*}{$P$} \\
\hline & Control & Enzyme & & \\
\hline \multicolumn{5}{|c|}{ Chemical composition of straw, $\%$ of DM } \\
\hline $\mathrm{DM}, \%$ & 82.1 & 82.5 & & \\
\hline $\mathrm{OM}$ & 83.9 & 84.0 & & \\
\hline $\mathrm{NDF}$ & 75.8 & 75.3 & & \\
\hline $\mathrm{ADF}$ & 48.4 & 48.8 & & \\
\hline $\mathrm{CP}$ & 5.15 & 5.44 & & \\
\hline WSC & 0.50 & 0.53 & & \\
\hline \multicolumn{5}{|l|}{ Intake, $\mathrm{kg} \cdot \mathrm{d}^{-1}$} \\
\hline $\mathrm{DM}$ & 9.0 & 8.8 & 0.34 & $<0.66$ \\
\hline $\mathrm{OM}$ & 8.3 & 8.2 & 0.32 & $<0.69$ \\
\hline NDF & 4.5 & 4.7 & 0.18 & $<0.27$ \\
\hline $\mathrm{ADF}$ & 2.7 & 2.8 & 0.11 & $<0.43$ \\
\hline $\mathrm{CP}$ & 1.1 & 1.1 & 0.04 & $<0.54$ \\
\hline Starch & 1.3 & 1.3 & 0.05 & $<0.71$ \\
\hline \multicolumn{5}{|l|}{ Digestibility, \% } \\
\hline $\mathrm{DM}$ & 65.7 & 65.3 & 0.86 & $<0.61$ \\
\hline $\mathrm{OM}$ & 67.1 & 66.6 & 0.86 & $<0.57$ \\
\hline NDF & 56.4 & 57.9 & 0.99 & $<0.18$ \\
\hline $\mathrm{ADF}$ & 51.5 & 52.9 & 1.11 & $<0.25$ \\
\hline $\mathrm{CP}$ & 67.9 & 67.1 & 0.72 & $<0.29$ \\
\hline Starch & 94.9 & 94.5 & 0.93 & $<0.31$ \\
\hline Average BW, kg & 767 & 768 & 33.5 & $<0.99$ \\
\hline
\end{tabular}

\footnotetext{
${ }^{1} \mathrm{WSC}=$ water-soluble carbohydrate.
}

${ }^{2}$ Treatments were: Control: without enzyme supplementation, sprayed with distilled water at $10 \%(\mathrm{vol} / \mathrm{wt})$ application rate $24 \mathrm{~h}$ before feeding. Enzyme: supplemented with recombinant fibrolytic enzyme which was diluted with distilled water and sprayed onto the barley straw at $10 \%(\mathrm{vol} / \mathrm{wt})$ application rate to achieve a rate of $6.6 \times 10^{4}$ $\mathrm{U} \cdot \mathrm{kg}^{-1}$ straw $24 \mathrm{~h}$ before feeding. and CP were unaffected by RFE supplementation due to the restricted level of feeding. Apparent digestibility of DM, OM, NDF, ADF, CP, and starch in the total digestive tract also did not differ between control and RFE.

\section{Ruminal pH and Fermentation Characteristics}

There were no differences in mean, minimum, and maximum ruminal $\mathrm{pH}$ or in the duration of $\mathrm{pH}<5.8$ between control and RFE (Table 3 ). However, the standard deviation (SD) of mean $\mathrm{pH}$ tended $(P<0.08)$ to be less for heifers fed RFE than control heifers. No treatment effect or treatment $\times$ time interaction was observed for the diurnal fluctuations in ruminal $\mathrm{pH}$ when they were averaged over the $6 \mathrm{~d}$ of measurement (Fig. 1). For both treatment groups, mean ruminal $\mathrm{pH}$ declined from 6.9 to 6.2 during the first $6 \mathrm{~h}$ after the morning

Table 3. Effects of recombinant fibrolytic enzyme supplementation on ruminal $\mathrm{pH}$, fermentation characteristics, protozoa, and enzyme activities in heifers fed a forage diet

\begin{tabular}{|c|c|c|c|c|}
\hline \multirow[b]{2}{*}{ Item } & \multicolumn{2}{|c|}{ Treatments $^{1}$} & \multirow[b]{2}{*}{ SEM } & \multirow[b]{2}{*}{$P$} \\
\hline & Control & Enzyme & & \\
\hline \multicolumn{5}{|l|}{ Ruminal pH } \\
\hline Mean & 6.52 & 6.51 & 0.043 & $<0.55$ \\
\hline Minimum & 5.79 & 5.80 & 0.085 & $<0.61$ \\
\hline Maximum & 7.07 & 7.03 & 0.032 & $<0.17$ \\
\hline $\mathrm{SD}$ of mean $\mathrm{pH}$ & 0.19 & 0.14 & 0.009 & $<0.08$ \\
\hline $\mathrm{pH}<5.8, \mathrm{~h} \cdot \mathrm{d}^{-1}$ & 0.78 & 0.49 & 0.184 & $<0.25$ \\
\hline \multicolumn{5}{|l|}{ Volatile fatty acids (VFA) } \\
\hline Total, $\mathrm{m} M$ & 106.9 & 105.9 & 1.38 & $<0.61$ \\
\hline Acetate (A), $\%$ & 68.37 & 68.21 & 1.353 & $<0.70$ \\
\hline Propionate (P), \% & 17.49 & 17.46 & 0.472 & $<0.86$ \\
\hline Butyrate, $\%$ & 10.10 & 10.17 & 0.691 & $<0.77$ \\
\hline $\mathrm{BCVFA}^{2}, \%$ & 2.13 & 2.25 & 0.096 & $<0.13$ \\
\hline $\mathrm{A}: \mathrm{P}$ & 3.94 & 3.93 & 0.173 & $<0.87$ \\
\hline $\mathrm{NH}_{3}-\mathrm{N}, \mathrm{m} M$ & 5.23 & 5.75 & 0.298 & $<0.06$ \\
\hline Protozoa counts, $\times 10^{5} \cdot \mathrm{mL}^{-1}$ & 8.06 & 8.55 & 0.314 & $<0.19$ \\
\hline \multicolumn{5}{|l|}{ Endogenous enzyme activity ${ }^{3}$} \\
\hline Xylanase & 115.0 & 116.9 & 13.64 & $<0.67$ \\
\hline Endoglucanase & 40.7 & 44.3 & 2.87 & $<0.08$ \\
\hline Exoglucanase & 4.0 & 4.1 & 0.18 & $<0.46$ \\
\hline
\end{tabular}

${ }^{1}$ Treatments were: Control: without enzyme supplementation, sprayed with distilled water at $10 \%(\mathrm{vol} / \mathrm{wt})$ application rate $24 \mathrm{~h}$ before feeding. Enzyme: supplemented with recombinant fibrolytic enzyme which was diluted with distilled water and sprayed onto the barley straw at $10 \%(\mathrm{vol} / \mathrm{wt})$ application rate to achieve a rate of $6.6 \times 10^{4}$ $\mathrm{U} \cdot \mathrm{kg}^{-1}$ straw $24 \mathrm{~h}$ before feeding.

${ }^{2}$ BCVFA = branch-chained VFA (isobutyrate + isovalerate).

${ }^{3}$ Xylanase activity was expressed as $\mu \mathrm{mol}$ xylose $\cdot \mathrm{min}^{-1} \cdot \mathrm{mL}^{-1}$ of wet rumen contents. Endoglucanase activity was expressed as $\mu \mathrm{mol}$ glucose $\mathrm{min}^{-1} \cdot \mathrm{mL}^{-1}$ of wet rumen contents. Exoglucanase activity was expressed as $\mu \mathrm{mol}$ of glucose $\cdot \mathrm{min}^{-1} \cdot \mathrm{mL}^{-1}$ of wet rumen contents. 


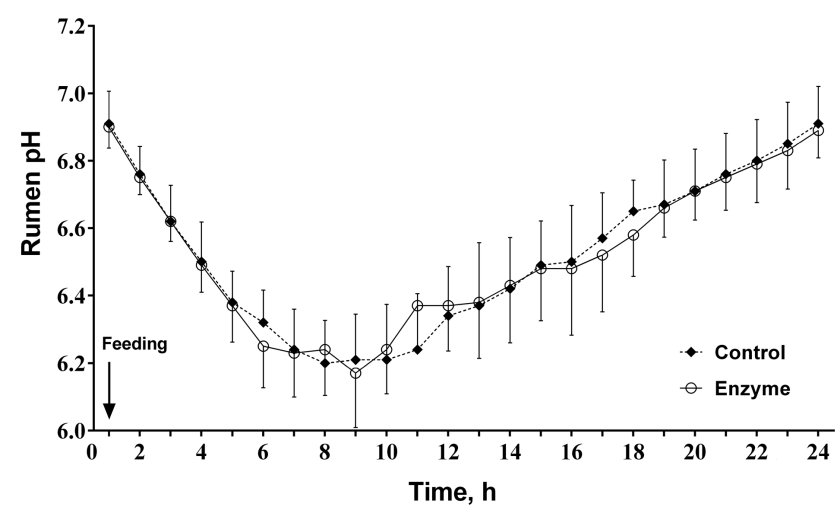

Figure 1. Effects of recombinant fibrolytic enzyme supplementation on diurnal fluctuation in mean ruminal $\mathrm{pH}$ of individual heifers averaged over $6 \mathrm{~d}$ of measurement. No treatment effect or treatment $\times$ time interaction $(P>0.05)$ was observed.

feeding, remained low from 6 to $16 \mathrm{~h}$ post-feeding, and steadily climbed thereafter to reach pre-feeding levels. Substantial individual animal variation in ruminal $\mathrm{pH}$, especially between 6 and $18 \mathrm{~h}$ postfeeding was noted.

Total ruminal VFA concentration and molar proportion of individual VFA were not different between control and RFE, and as a result the ratio of acetate to propionate also did not differ between treatments (Table 3). However, ruminal $\mathrm{NH}_{3}-\mathrm{N}$ concentration tended $(P<0.06)$ to be greater with RFE as compared to control. The protozoa counts $(P<0.19)$ were 8.06 and $8.55 \times$ $10^{5} \mathrm{~mL}^{-1}$ for control and RFE heifers, respectively. No differences in endogenous xylanase and exoglucanase activity in rumen contents between control and RFE were observed, whereas heifers supplemented with RFE tended $(P<0.08)$ to have greater endoglucanase activity than did control heifers.

\section{Nitrogen Balance and Microbial Protein Synthesis}

Intake of $\mathrm{N}$ and amount of fecal and urinary $\mathrm{N}$ excreted did not differ between control and RFE (Table 4). No treatment effects were observed for fecal or urinary $\mathrm{N}$, either expressed as percent of $\mathrm{N}$ intake or percent of excreted $\mathrm{N}$. There were also no differences between treatments in urinary $\mathrm{N}$ excreted in the form of urea $\mathrm{N}$ and $\mathrm{NH}_{3}-\mathrm{N}$ expressed as daily amount or percent of total urine. The apparent retained $\mathrm{N}$ was negative and was not affected by treatments, with an average weight loss of $8 \mathrm{~kg}$ of $\mathrm{BW}$ of all heifers over the study.

Urinary excretion of allantoin, uric acid, and total PD, as well as the endogenous PD, did not differ between control and RFE (Table 4). Additionally,
Table 4. Effects of recombinant fibrolytic enzyme supplementation on $\mathrm{N}$ balance and ruminal microbial protein synthesis in heifers fed forage diet

\begin{tabular}{|c|c|c|c|c|}
\hline \multirow[b]{2}{*}{ Item } & \multicolumn{2}{|c|}{ Treatments $^{1}$} & \multirow[b]{2}{*}{ SEM } & \multirow[b]{2}{*}{$P$} \\
\hline & Control & Enzyme & & \\
\hline$\overline{\mathrm{N} \text { intake, } \mathrm{g} \cdot \mathrm{d}^{-1}}$ & 173.4 & 170.9 & 6.79 & $<0.49$ \\
\hline Total excreted $\mathrm{N}, \mathrm{g} \cdot \mathrm{d}^{-1}$ & 186.7 & 187.6 & 8.33 & $<0.92$ \\
\hline \multicolumn{5}{|l|}{ Fecal N } \\
\hline$g \cdot d^{-1}$ & 58.9 & 59.4 & 2.79 & $<0.81$ \\
\hline$\%$ of intake $\mathrm{N}$ & 34.0 & 34.8 & 0.71 & $<0.24$ \\
\hline$\%$ of excreted $\mathrm{N}$ & 32.2 & 31.6 & 1.20 & $<0.74$ \\
\hline \multicolumn{5}{|l|}{ Urine $\mathrm{N}$} \\
\hline \multicolumn{5}{|l|}{ Total N } \\
\hline $\mathrm{g} \cdot \mathrm{d}^{-1}$ & 127.8 & 128.2 & 6.98 & $<0.96$ \\
\hline$\%$ of intake $\mathrm{N}$ & 73.7 & 75.0 & 4.14 & $<0.85$ \\
\hline$\%$ of excreted $\mathrm{N}$ & 67.8 & 68.4 & 1.20 & $<0.74$ \\
\hline \multicolumn{5}{|l|}{ Urea $\mathrm{N}$} \\
\hline $\mathrm{g} \cdot \mathrm{d}^{-1}$ & 67.6 & 67.4 & 4.25 & $<0.97$ \\
\hline$\%$ of urine $\mathrm{N}$ & 53.1 & 53.0 & 4.25 & $<0.93$ \\
\hline \multicolumn{5}{|l|}{$\mathrm{NH}_{3}-\mathrm{N}, \mathrm{g} \cdot \mathrm{d}^{-1}$} \\
\hline$g \cdot d^{-1}$ & 0.62 & 0.78 & 0.121 & $<0.19$ \\
\hline$\%$ of urine $\mathrm{N}$ & 0.49 & 0.62 & 0.103 & $<0.20$ \\
\hline Apparent retained $\mathrm{N}, \mathrm{g} \cdot \mathrm{d}^{-1}$ & -13.3 & -16.7 & 3.19 & $<0.63$ \\
\hline \multicolumn{5}{|l|}{ Urinary PD excretion, $\mathrm{mmol} \cdot \mathrm{d}^{-1}$} \\
\hline Allantoin & 163.6 & 163.4 & 12.85 & $<0.98$ \\
\hline Uric acid & 12.0 & 11.9 & 1.69 & $<0.83$ \\
\hline Total & 175.6 & 175.3 & 14.30 & $<0.97$ \\
\hline Endogenous $\mathrm{PD}^{2}, \mathrm{mmol}^{-\mathrm{d}^{-1}}$ & 57.6 & 57.5 & 1.35 & $<0.77$ \\
\hline PD absorption ${ }^{3}, \mathrm{mmol}^{-\mathrm{d}^{-1}}$ & 138.9 & 138.6 & 15.68 & $<0.98$ \\
\hline $\begin{array}{l}\text { Microbial protein synthesis }{ }^{4} \text {, } \\
\mathrm{g} \mathrm{N}^{-\mathrm{d}^{-1}}\end{array}$ & 90.8 & 90.6 & 10.25 & $<0.98$ \\
\hline
\end{tabular}

${ }^{1}$ Treatments were: Control: without enzyme supplementation, sprayed with distilled water at $10 \%(\mathrm{vol} / \mathrm{wt})$ application rate $24 \mathrm{~h}$ before feeding. Enzyme: supplemented with recombinant fibrolytic enzymes which was diluted with distilled water and sprayed onto the barley straw at $10 \%(\mathrm{vol} / \mathrm{wt})$ application rate to achieve a rate of $6.6 \times 10^{4}$ $\mathrm{U} \cdot \mathrm{kg}^{-1} 24 \mathrm{~h}$ before feeding.

${ }^{2} \mathrm{PD}=$ purine derivatives. Excretion of the endogenous PD was assumed constant at $0.385 \mathrm{mmol} \cdot \mathrm{kg}^{-1}$ of $\mathrm{BW}^{0.75}$.

${ }^{3}$ Microbial origin purine $=($ total PD excreted - endogenous $\mathrm{PD}) / 0.85$.

${ }^{4}$ Synthesis of ruminal microbial protein $=($ purine absorption $\times 70) /$ (purine $\mathrm{N}$ :total $\mathrm{N}$ in mixed rumen bacteria $\times 0.83 \times 1,000$ ).

PD absorption of bacterial origin and bacterial $\mathrm{N}$ production did not differ between the 2 treatments.

\section{DISCUSSION}

Promising results in terms of the ability of recombinant enzyme XYL10C to improve the digestion of plant material in the presence of ruminal microorganisms were obtained in our previous microassay (Badhan et al., 2014) and in vitro batch culture study (Ribeiro et al., 2018), but not in a Rusitec continuous culture system (Ribeiro et al., 2018). After $48 \mathrm{~h}$ of batch culture incubation, the 
disappearance of DM, NDF, and ADF was increased by $3.3 \%, 3.4 \%$, and $3.9 \%$, respectively, when XYL10C was applied at $500 \mu \mathrm{g}$ of protein per gram of barley straw DM (Ribeiro et al., 2018). Thus, the current in vivo study was conducted based on the microassay and batch culture results. However, the inability of XYL10C to improve fiber digestion in the present in vivo study is in contrast to the microassay and batch culture results, although it is consistent with the lack of response observed in the Rusitec system (Ribeiro et al., 2018). It was assumed that the larger particle size of the samples incubated in the RUSITEC when compared with batch cultures reduced the surface area and restricted enzyme access to substrates, thereby limiting the beneficial effects of RFE (Ribeiro et al., 2015, 2018). Thus, we suggest that assessment of enzymes in continuous culture (Rusitec) may be a more accurate reflection of responses in vivo than batch culture assessment. Furthermore, although the microassay we developed has the capacity to screen large numbers of recombinant enzymes for their synergy with mixed ruminal enzymes, it alone does not predict in vivo responses. Similar inconsistencies between in vitro and in vivo responses has been observed for other additives such as humic substances (HS) which were found to reduce $\mathrm{CH}_{4}$ emission in batch cultures, but not in where HS consistently decreased $\mathrm{CH}_{4}$ production when included at $3.6 \mathrm{mg} \cdot \mathrm{mL}^{-1}$ of inoculum during a $48-\mathrm{h}$ incubation in batch culture (Sheng et al., 2018), but not in the Rusitec (Terry et al., 2018b) or in heifers (Terry et al., 2018a).

The main difference between batch and continuous culture systems is that the latter allows for the adaptation of rumen microbes to the feed substrate and additive during testing. Therefore, it is possible that the lack of effect of XYL10C on feed digestibility in Rusitec (Ribeiro et al., 2018) and in the current in vivo study was due to adaptation of the rumen microbes to the added exogenous enzyme before the sampling period. This suggestion is supported by a parallel study we conducted using growing lambs fed a forage diet treated with this same enzyme as it improved the average daily gain of lambs for the first $28 \mathrm{~d}$, but not throughout the entire feeding period (data unpublished). In addition, we also speculate that the failure of XYL10C to improve the fiber digestibility may have resulted from the relatively prolonged retention time of feeds in the rumen as a result of restricted feed intake during the sample collection period. Feed intake level is negatively correlated to ruminal retention time of feeds (Grovum and Williams, 1977).
Beauchemin and Holtshausen (2010) indicated that exogenous enzymes mostly increase the rate, rather than extent, of feed degradation in the rumen. Therefore, an increased retention time of fiber in the rumen could possibly offset any improvement in rate of fiber digestion due to RFE. Finally, it is possible that the dose (calculated on the basis of enzyme applied to substrate) used in the present in vivo study, which was one-third that used in the in vitro study of Ribeiro et al. (2018), was insufficient to elicit any improvements in fiber digestion.

\section{Effects of RFE on Feed Intake and Digestibility}

Pre-treatment effects of applying exogenous enzymes onto plant fiber prior to ingestion by beef cattle have been reported (Beauchemin et al., 2003, 2004). Several mechanisms to explain these pretreatment effects have been suggested including initial hydrolysis of plant fiber liberating nutrients that enhance microbial growth and colonization of feed particles; alteration of the plant cell wall molecular structure that expose microbial attachment sites and enable penetration into the interior of plant cells; and enhanced binding of exogenous enzyme to feed offering a measure of protection of the enzyme from proteolysis in the rumen (Beauchemin et al., 2004). Enzyme pre-treatment has been shown to release reducing sugars (Wang et al., 2001) as a result of the partial solubilization of NDF and ADF (Krause et al., 1998; Wang et al., 2001). In a study by Ribeiro et al. (2018), recombinant enzyme XYL10C in combination with a mixture of rumen enzymes increased total sugar release in buffer by $206 \%$ as compared to mixed rumen enzymes alone in an in vitro microassay. However, pre-treatment of barley straw with XYL10C had no effect on the chemical composition, including the WSC content of barley straw. This discrepancy may reflect differences in the method of enzyme application, or that synergistic responses are only observed when XYL10C is in the presence of mixed rumen enzymes. Feng et al. (1996) reported no changes in the nutrient composition of hay treated with commercial fibrolytic enzymes (i.e., cellulases and xylanases) immediately before feeding, or grass forage treated with fibrolytic enzymes at cutting or wilting. Alvarez et al. (2009) also reported that spraying fibrolytic enzymes (Fibrozyme, Alltech Inc., Nicholasville, KY) onto oat straw or wheat middlings $24 \mathrm{~h}$ before feeding had no impact on the NDF or ADF content of these feeds. Although a reduction in NDF and ADF was noticed when EFEs were applied to barley grain $24 \mathrm{~h}$ prior to feeding 
(Krause et al., 1998; Wang et al., 2001), the NDF content of alfalfa hay was unchanged after $24 \mathrm{~h}$ of contact with these same enzymes (Wang et al., 2001). These findings suggest that pre-treatment of forages with firbrolytic enzymes may not be as effective at solubilizing plant cell wall carbohydrates as they are when applied to grain.

Lack of effect of RFE supplementation on intake of DM, OM, and NDF was expected because heifers were fed at $90 \%$ of ad libitum intake. At ad libitum feeding, studies have reported either no effect of fibrolytic enzymes on DM intake (Lewis et al., 1996; Alvarez et al., 2009; Salem et al., 2013) or increased DM intake in dairy (Lewis et al., 1999) and beef cattle (Feng et al., 1996; Zinn and Salinas, 1999). It was suggested that the increase in DM intake with EFE was caused by increased ruminal particulate passage rate or increased fiber digestion in the rumen. However, in a recent meta-analysis, Arriola et al. (2017) concluded that fibrolytic enzymes did not affect the DM intake of dairy cows.

The effects of fibrolytic enzymes on feed digestibility have been inconsistent among studies, possibly related to the application method, source and dose of enzymes, diet or nutritional requirements of the animal. Arriola et al. (2016) conducted a metaanalysis with 17 experiments and 36 observations and found that treatment of the diet with fibrolytic enzymes only resulted in a small increase in total tract DM and NDF digestibility in lactating dairy cows.

\section{Effects of RFE on Ruminal pH and Fermentation}

It has been proposed that EFEs stimulate rumen microbial populations, resulting in an improvement in ruminal fermentation and feed digestion (Beauchemin et al., 2003). Application of fibrolytic enzymes has led to increased populations of ruminal cellulolytic bacteria (Wang et al., 2001; Nsereko et al., 2002), and enhanced bacterial colonization of substrates (Wang et al., 2012). Chung et al. (2012) reported that the numbers of the ruminal fibrolytic bacterium, Fibrobacter succinogenes and the nonfibrolytic bacteria, Ruminococcus amylophilus and Selenomonas ruminantium increased or tended to linearly increase with increasing dosages of EFEs. Ruminal and exogenous enzymes may work synergistically to increase the hydrolytic potential within the rumen environment, and this is likely a significant mechanism whereby enzyme additives improve feed digestion (Morgavi et al., 2000). Moreover, it is reported that exogenous enzymes increased xylanase and cellulose activities in ruminal fluid of cattle (Hristov et al., 1998). In the current study, although ruminal xylanase and exoglucanase activities were not affected by the addition of XYL10C, the tendency for greater ruminal endoglucanase activity is consistent with the in vitro findings of Ribeiro et al. (2018), who also reported an increase in endoglucanase activity and microbial $\mathrm{N}$ production associated when barley straw was treated with XYL10C prior to incubation in batch cultures.

The lack of effect of RFE on rumen fermentation variables is consistent with the lack of effect on total tract digestibility, and suggests that XYL10C had minimal effects on ruminal fiber digestion. The lack of RFE effects on ruminal $\mathrm{pH}$, total VFA concentration, and molar proportions of individual VFA are in agreement with several previous studies with fibrolytic enzymes (Krause et al., 1998; Chung et al., 2012). However, the tendency for less variation in mean ruminal $\mathrm{pH}$ with RFE suggests improved stability of ruminal $\mathrm{pH}$. A change in ruminal fermentation patterns may occur when exogenous enzymes improve ruminal fiber digestion, leading to greater molar proportion of acetate and lower molar proportions of propionate (Yang et al., 1999). Similarly, Ribeiro et al. (2018) reported increased in vitro total VFA concentration and proportions of acetate, and lowered proportion of propionate with another RFE (XYL10A). However, none of these changes in VFA profiles were observed in Rusitec study (Ribeiro et al., 2018) and in this in vivo study.

The greater ruminal $\mathrm{NH}_{3}-\mathrm{N}$ concentration in heifers fed RFE-treated barley straw is consistent with the in vitro observation of Ribeiro et al. (2018) where addition of XYL10C increased concentrations of rumen $\mathrm{NH}_{3}-\mathrm{N}$ and $\mathrm{N}$ disappearance. Although the pre-treatment of barley straw with RFE added a very small amount of $\mathrm{N}$, it was unlikely to have had significant impact on ruminal ammonia levels due to its low quantity. The results suggest that pre-treating barley straw with XYL10C may have increased ruminal protein degradability because ruminal microbial protein synthesis did not differ between control and RFE.

\section{Effects of RFE on N Balance and Microbial Protein Synthesis}

The $\mathrm{N}$ utilization was not affected by RFE, and heifers from both control and RFE groups exhibited negative $\mathrm{N}$ balance. In addition, the heifers used in this study were mature and BW change was negative with an average weight loss of $8 \mathrm{~kg}$ of BW over the study. Feeding exogenous enzymes appears to elicit positive responses in $\mathrm{N}$ utilization for highproducing animals rather than for animals fed at 
maintenance (Beauchemin et al., 2003). Yang et al. (1999) also found that intake and duodenal flow of $\mathrm{N}$ were not affected by exogenous enzymes that contained primarily cellulase and xylanase activities.

Purine derivatives including allantoin and uric acid in urine are often used as indicators of ruminal microbial protein synthesis (Zinn and Owens, 1986). Several studies have shown that application of fibrolytic enzyme increased microbial protein synthesis (Yang et al., 1999; Gado et al., 2009; Salem et al., 2013). Treatment of steam-rolled barley grain with fibrolytic enzymes (predominantly xylanase activity) increased the incorporation of $\mathrm{N}$ into feed particle associated and feed particle bound bacteria in Rusitec (Wang et al., 2001). However, in the current study, the lack of effect of XYL10C on urinary $\mathrm{PD}$ excretion and microbial protein synthesis is in agreement with Ribeiro et al. (2018), who showed that XYL10C did not increase microbial protein synthesis in the Rusitec, despite increasing the amount of microbial $\mathrm{N}$ associated with straw particles.

In conclusion, spraying XYL10C onto barley straw $24 \mathrm{~h}$ prior to feeding did not affect total tract digestibility of DM, OM, NDF, and ADF, ruminal $\mathrm{pH}$, fermentation characteristics, microbial protein synthesis, or $\mathrm{N}$ utilization in beef heifers. However, the tendency of increased ruminal $\mathrm{NH}_{3}-\mathrm{N}$ concentration without altering microbial protein synthesis indicated that adding XYL10C may increase ruminal proteolytic activity. The inconsistent effects of XYL10C on fiber digestibility in in vitro batch culture studies compared with continuous culture and in vivo studies suggest that factors such as feed particle size, rumen retention time, and microbial adaptation may influence the mode of action of exogenous enzymes. The results of the current study are in accordance with the Rusitec study reported by Ribeiro et al. (2018), and indicate that assessment of enzymes in continuous culture (Rusitec) may be a more accurate reflection of responses in vivo than batch culture. Developing RFEs that improve fiber digestion in ruminants remains a challenging, but important, undertaking for future research.

\section{LITERATURE CITED}

Alvarez, G., J. M. Pinos-Rodriguez, J. G. Herrera, J. C. Garcia, S. S. Gonzalez, and R. Barcena. 2009. Effects of exogenous fibrolytic enzymes on ruminal digestibility in steers fed high fiber rations. Livest. Sci. 121:150-154. doi:10.1016/j. livsci.2008.05.024

Arriola, K. G., A. S. Oliveira, Z. X. Ma, I. J. Lean, M. C. Giurcanu, and A. T. Adesogan. 2017. A metaanalysis on the effect of dietary application of exogenous fibrolytic enzymes on the performance of dairy cows. J. Dairy Sci. 100:4513-4527. doi:10.3168/jds.2016-12103
Association of Official Analytical Chemists (AOAC) International. 2005. Official methods of analysis. 18th ed. AOAC International, Gaithersburg, MD.

Badhan, A., Y. Wang, R. Gruninger, D. Patton, J. Powlowski, A. Tsang, and T. McAllister. 2014. Formulation of enzyme blends to maximize the hydrolysis of alkaline peroxide pretreated alfalfa hay and barley straw by rumen enzymes and commercial cellulases. BMC Biotechnol. 14:31. doi:10.1186/1472-6750-14-31

Bailey, M. J., P. Biely, and K. Poutanen. 1992. Interlaboratory testing of methodsforassay of xylanaseactivity.J.Biotechnol. 23:257-270. doi:10.1016/0168-1656(92)90074-J

Beauchemin, K. A., D. Colombatto, D. P. Morgavi, and W. Z. Yang. 2003. Use of exogenous fibrolytic enzymes to improve feed utilization by ruminants. J. Anim. Sci. 81(E. Suppl.):E37-E47. doi:10.2527/2003.8114_suppl_2E37x

Beauchemin, K. A., D. Colombatto, D. P. Morgavi, W. Z. Yang, and L. M. Rode. 2004. Mode of action of exogenous cell wall degrading enzymes for ruminants. Can. J. Anim. Sci. 84:13-22. doi:10.4141/A02-102

Beauchemin, K. A., and L. Holtshausen. 2010. Development in enzyme usage in ruminants. In: M. Bedford and G. Partridge, editors, Enzymes in farm animal nutrition. CABI Publishing, Wallingford, Oxon, UK. p. 206-230.

Canadian Council on Animal Care. 2009. CCAC guidelines on: The care and use of farm animals in research, teaching and testing. In: E. D. Olfert, B. M. Cross, and A. A. McWilliam, editors, Canadian Council on Animal Care, Ottawa, ON, Canada.

Chen, X. B., and M. J. Gomes. 1992. Estimation of microbial protein supply to sheep and cattle based on urinary excretion of purine derivatives - an overview of the technical details. Int. Feed Res. Unit, Occ. Publ., Rowett Research Institute, Bucksburn, Aberdeen, UK.

Chung, Y. H., M. Zhou, L. Holtshausen, T. W. Alexander, T. A. McAllister, L. L. Guan, M. Oba, and K. A. Beauchemin. 2012. A fibrolytic enzyme additive for lactating Holstein cow diets: ruminal fermentation, rumen microbial populations, and enteric methane emissions. J. Dairy Sci. 95:1419-1427. doi:10.3168/jds.2011-4552

Feng, P., C. W. Hunt, G. T. Pritchard, and W. E. Julien. 1996. Effect of enzyme preparations on in situ and in vitro degradation and in vivo digestive characteristics of mature cool-season grass forage in beef steers. J. Anim. Sci. 74:1349-1357. doi:10.2527/1996.7461349x

Gado, H. M., A. Z. M. Salem, P. H. Robinson, and M. Hassan. 2009. Influence of exogenous enzymes on nutrient digestibility, extent of ruminal fermentation as well as milk production and composition in dairy cows. Anim. Feed Sci. Tech. 154:36-46. doi:10.1016/j.anifeedsci.2009.07.006

Grovum, W. L., and V. J. Williams. 1977. Rate of passage of digesta in sheep. 6. The effect of level of food intake on mathematical predictions of the kinetics of digesta in the reticulorumen and intestines. Br. J. Nutr. 38:425-436.

Hatanaka, C., and Y. Kobara. 1980. Determination of glucose by a modification of Somogyi-Nelson method. Agric. Biol. Chem. 44:12, 2943-2949, doi:10.1080/00021369.1980.10864408

Hristov, A. N., T. A. McAllister, and K. J. Cheng. 1998. Stability of exogenous polysaccharide-degrading enzymes in the rumen. Anim. Feed Sci. Tech. 76:161-168. doi:10.1016/ S0377-8401(98)00217-X

Krause, M., K. A. Beauchemin, L. M. Rode, B. I. Farr, and P. Nørgaard. 1998. Fibrolytic enzyme treatment of barley grain and source of forage in high-grain diets 
fed to growing cattle. J. Anim. Sci. 76:2912-2920. doi: $10.2527 / 1998.76112912 x$

Lewis, G. E., C. W. Hunt, W. K. Sanchez, R. Treacher, G. T. Pritchard, and P. Feng. 1996. Effect of direct-fed fibrolytic enzymes on the digestive characteristics of a forage-based diet fed to beef steers. J. Anim. Sci. 74:3020 3028. doi: $10.2527 / 1996.74123020 x$

Lewis, G. E., W. K. Sanchez, C. W. Hunt, M. A. Guy, G. T. Pritchard, B. I. Swanson, and R. J. Treacher. 1999. Effect of direct-fed fibrolytic enzymes on the lactational performance of dairy cows. J. Dairy Sci. 82:611-617. doi:10.3168/jds.S0022-0302(99)75274-4

Lindberg, J. E., and C. Jansson. 1989. A rapid automated analysis of allantoin in ruminant urine. Swed. J. Agric. Res. 19:163-168.

McAllister, T. A., A. N. Hristov, K. A. Beauchemin, L. M. Rode, and K. J. Cheng. 2001. Enzymes in ruminant diets. In: M. Bedford and G. Partridge, editors, Enzymes in farm animal nutrition. CABI Publishing, Wallingford, Oxon, UK. p. 273-298.

Meale, S. J., Beauchemin, K. A., Hristov, A. N., Chaves, A. V. and McAllister, T. A. 2014. Board-invited review: opportunities and challenges in using exogenous enzymes to improve ruminant production. J. Anim. Sci. 92(2):427-442. doi:10.2527/jas.2013-6869

Morgavi, D. P., K. A. Beauchemin, V. L. Nsereko, L. M. Rode, A. D. Iwaasa, W. Z. Yang, T. A. McAllister, and Y. Wang. 2000. Synergy between ruminal fibrolytic enzymes and enzymes from Trichoderma longibrachiatum. J. Dairy Sci. 83:1310-1321. doi:10.3168/jds.S0022-0302(00)74997-6

Nsereko, V. L., K. A. Beauchemin, D. P. Morgavi, L. M. Rode, A. F. Furtado, T. A. McAllister, A. D. Iwaasa, W. Z. Yang, and Y. Wang. 2002. Effect of a fibrolytic enzyme preparation from Trichoderma longibrachiatum on the rumen microbial population of dairy cows. Can. J. Microbiol. 48:14-20. doi:10.1139/w01-131

Phakachoed, N., W. Suksombat, D. Colombatto, and K. A. Beauchemin. 2013. Use of fibrolytic enzymes additives to enhance in vitro ruminal fermentation of corn silage. Livest. Sci. 157:100-112. doi:10.1016/j.livsci.2013.06.020

Rhine, E. D., G. K. Sims, R. L. Mulvaney, and E. J. Pratt. 1998. Improving the Berthelot reaction for determining ammonium in soil extracts and water. Soil Sci. Soc. Am. J. 62:473480. doi:10.2136/sssaj1998.03615995006200020026x

Ribeiro, G. O., A. Badhan, J. L. Huang, K. A. Beauchemin, W. Z. Yang, Y. X. Wang, A. Tsang, and T. A. McAllister. 2018. New recombinant fibrolytic enzymes for improved in vitro ruminal fiber degradability of barley straw. J. Anim. Sci. 96:3928-3942. doi:10.1093/jas/sky251

Ribeiro, G. O., L. C. Gonçalves, L. G. Pereira, A. V. Chaves, Y. Wang, K. A. Beauchemin, and T. A. McAllister. 2015. Effect of fibrolytic enzymes added to a Andropogon gayanus grass silage-concentrate diet on rumen fermentation in batch cultures and the artificial rumen (Rusitec). Animal 9:1153-1162. doi:10.1017/S1751731115000221

Ribeiro, G. O., R. J. Gruninger, A. Badhan, and T. A. McAllister. 2016. Mining the rumen for fibrolytic feed enzymes. Anim. Front. 6:20-26. doi:10.2527/af.2016-0019

Rode, L. M., W. Z. Yang, and K. A. Beauchemin. 1999. Fibrolytic enzyme supplements for dairy cows in early lactation. J. Dairy Sci. 82:2121-2126. doi:10.3168/jds.S0022-0302(99)75455-X

Salem, A. Z. M., H. M. Gado, D. Colombatto, and M. M. Y. Elghandour. 2013. Effects of exogenous enzymes on nutrient digestibility, ruminal fermentation and growth performance in beef steers. Livest. Sci. 154:69-73. doi:10.1016/j.livsci.2013.02.014

Sheng, P., G. O. Ribeiro Jr, Y. X. Wang, and T. A. McAllister. 2018. Humic substances reduce ruminal methane production and increases the efficiency of microbial protein synthesis in vitro. J. Sci. Food Agr. 99:2152-2157. doi:10.1002/ jsfa.9407

Sung, H. G., Y. Kobayashi, J. Chang, A. Ha, I. H. Hwang and J. K. Ha. 2007. Low ruminal $\mathrm{pH}$ reduces dietary fiber digestion via reduced microbial attachment. Asian-Australas. J. Anim. Sci. 20:200-207. doi:10.5713/ajas.2007.200

Terry, S A., G. de Oliveira Ribeiro, R. J. Gruninger, M. Hunerberg, S. Peng, A. V. Chaves, J. Burlet, K. A. Beauchemin, and T. A. McAllister. 2018a. Effect of humic substances on rumen fermentation, nutrient digestibility, methane emissions and rumen microbiota in beef heifers. J. Anim. Sci. 96:3863-3877. doi:10.1093/jas/sky265

Terry, S. A., A. F. O. Ramos, D. B. Holman, T. A. McAllister, G. Breves, and A. V. Chaves. 2018b. Humic substances alter ammonia production and the microbial populations within a RUSITEC fed a mixed hay - concentrate diet. Front. Microbiol. 9:1410. doi:10.3389/fmicb.2018.01410

Tirado-Gonzalez, D. N., L. A. Miranda-Romero, A. Ruiz-Flores, S. E. Medina-Cuellar, R. Ramirez-Valverde, and G. TiradoEstrada. 2018. Meta-analysis: effects of exogenous fibrolytic enzymes in ruminant diets. J. Appl. Anim. Res. 46:771-783, doi:10.1080/09712119.2017.1399135

Van Soest, P. J., J. B. Robertson, and B. A. Lewis. 1991. Methods for dietary fiber, neutral detergent fiber, and nonstarch polysaccharides in relation to animal nutrition. J. Dairy Sci. 74:3583-3597. doi:10.3168/jds. S0022-0302(91)78551-2

Wang, Y., T. A. McAllister, L. M. Rode, K. A. Beauchemin, D. P. Morgavi, V. L. Nsereko, A. D. Iwaasa, and W. Yang. 2001. Effects of an exogenous enzyme preparation on microbial protein synthesis, enzyme activity and attachment to feed in the rumen simulation technique (Rusitec). Br. J. Nutr. 85:325-332.

Wang, Y., J. E. Ramirez-Bribiesca, L. J. Yanke, A. Tsang, and T. A. McAllister. 2012. Effect of exogenous fibrolytic enzyme application on the microbial attachment and digestion of barley straw in vitro. Asian-Australas. J. Anim. Sci. 25:66-74. doi:10.5713/ajas.2011.11158

Wood, T. M., and M. K. Bhat. 1988. Methods for measuring cellulase activities. In: W. A. Wood and S. T. Kellogg, editors. Methods in enzymology. Vol. 160. Academic Press Inc., London, UK. p. 87-112.

Yang, W. Z., and K. A. Beauchemin. 2006. Physically effective fiber: method of determination and effects on chewing, ruminal acidosis, and digestion by dairy cows. J. Dairy Sci. 89:2618-2633. doi:10.3168/jds.S0022-0302(06)72339-6

Yang, W. Z., K. A. Beauchemin, and L. M. Rode. 1999. Effects of an enzyme feed additive on extent of digestion and milk production of lactating dairy cows. J. Dairy Sci. 82:391-403. doi:10.3168/jds.S0022-0302(99)75245-8

Zinn, R. A., and F. N. Owens. 1986. A rapid procedure for purine measurement and its use for estimating net ruminal protein synthesis. Can. J. Anim. Sci. 66:157-166. doi: $10.4141 /$ cjas $86-017$

Zinn, R. A., and J. Salinas. 1999. Influence of fibrozyme on digestive function and growth performance of feedlot steers fed a 78\% concentrate growing diet. In: Proc. Alltech's Fifteenth Annual Symposium. Nottingham University Press, Loughborough, UK. p. 313-319. 